Page 1 of 2

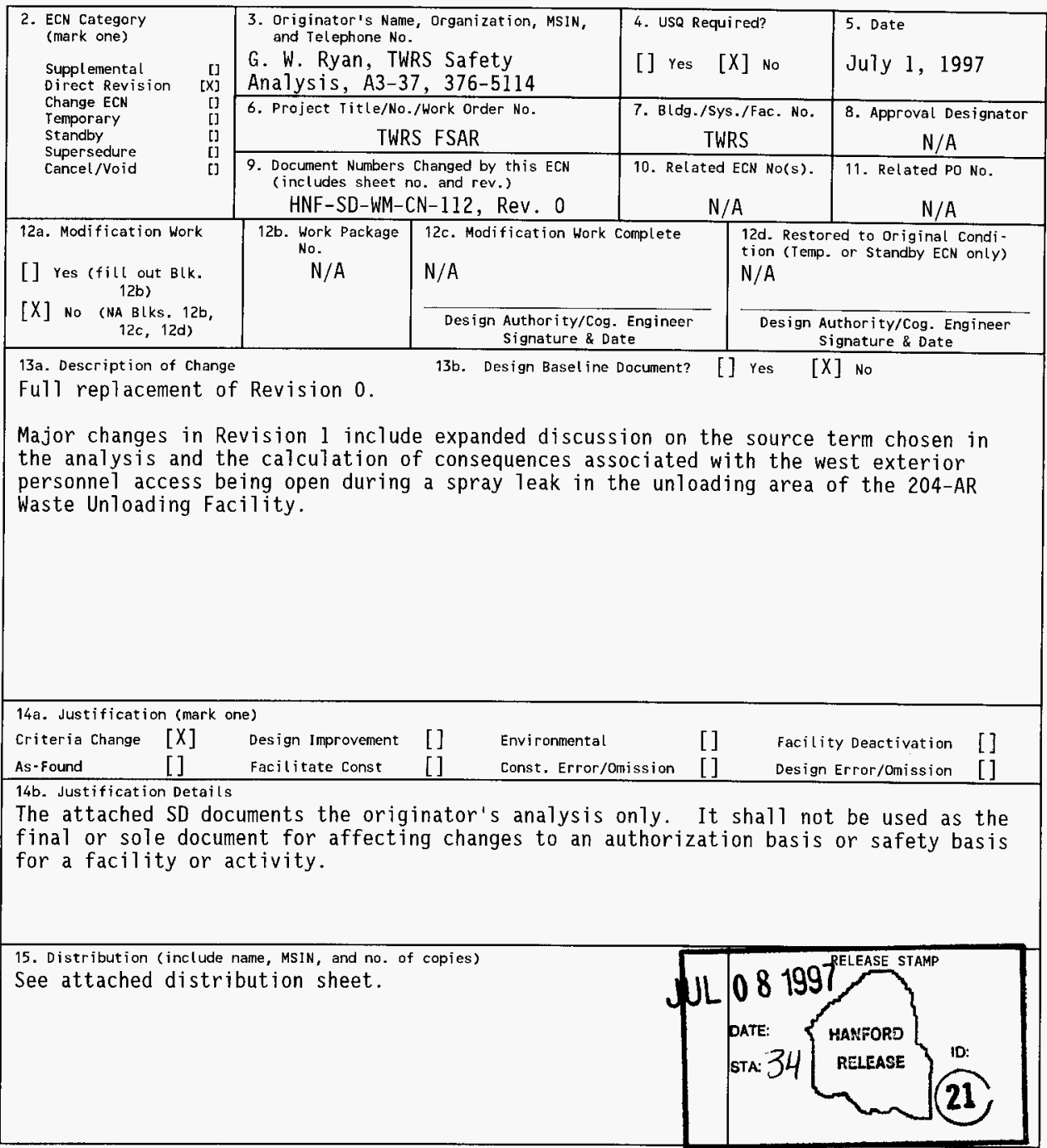




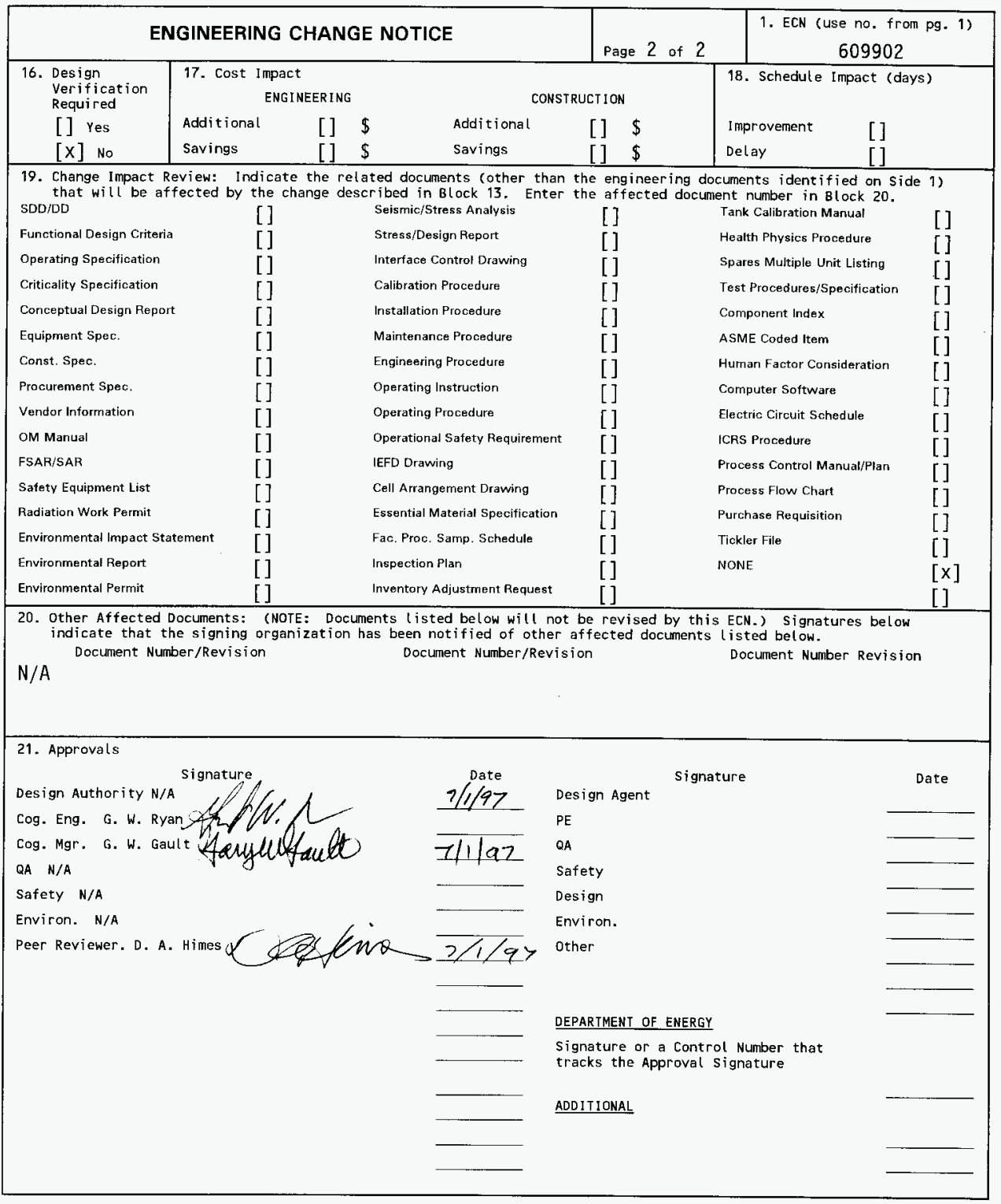




\section{Effects of a Spray Leak Inside the Unloading Area of the 204-AR Waste Unloading Facility.}

Grant W. Ryan

DE\&S Hanford, Inc., Richland, WA 99352

U.S. Department of Energy Contract DE-AC06-96RL13200

C. H. Huang

Fluor Daniel Northwest, Inc., Richland, WA 99352

U.S. Department of Energy Contract DE-AC06-96RL13200

EDT/ECN: 609902

Org Code: $2 \mathrm{~N} 170$

B\&R Code: EW3120071

UC: 510

Charge Code: E61381

Tota1 Pages: 35,36

Key Words: spray, spray leak, aerosol, TWRS, tank farms, 204-AR Waste Unloading Facility, crack, transfer line.

Abstract: This document presents the radiological dose and toxicological exposure calculations for a spray leak inside the unloading area of the 204-AR Waste Unloading Facility.

TRADEMARK DISCLAIMER. Reference herein to any specific comercial product, process, or service by trade name, trademark, manufacturer, or otherwise, does not necessarily constitute or imply its endorsement, recommendation, or favoring by the United States Government or any agency thereof or $i$ ts contractors or subcontractors.

Printed in the United States of America. To obtain copies of this document, contact: WHC/BCS Document Control Services, P.O. Box 1970, Mailstop H6-08, Richland WA 99352, Phone (509) 372-2420; Fax (509) 376-4989.
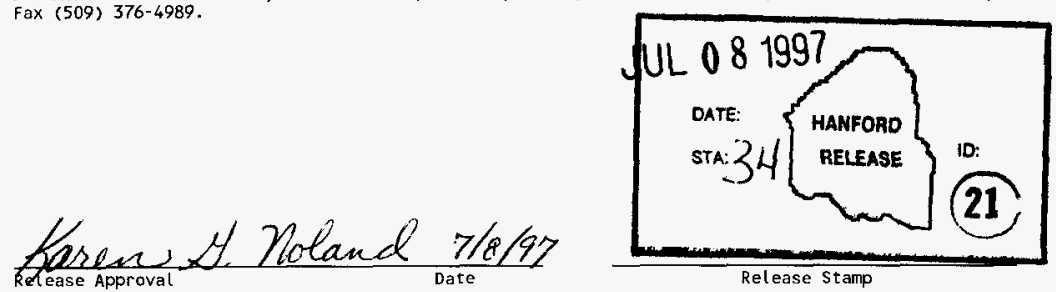

Approved for Public Release 


\section{RECORD OF REVISION}

(1) Document Number

HNF-SD-WM-CN-112

(2) Title

Effects of a Spray Leak Inside the Unloading Area of the 204-AR Waste Unloading

Facility.

CHANGE CONTROL RECORD

\begin{tabular}{|c|c|c|c|}
\hline \multirow{2}{*}{ Revision } & \multirow{2}{*}{ (4) Description of Change - Replace, Add, and Delete Pages } & \multicolumn{2}{|c|}{ Authorized for Release } \\
\hline & & (5) Cog. Engr. & (6) Cog. Mgr. \\
\hline 0 & (7) Origina? issue via EDT\#621240. & $\begin{array}{l}\text { C. H. Huang } \\
5 / 23 / 97\end{array}$ & $\begin{array}{l}\text { B. E. Hey } \\
5 / 27 / 97\end{array}$ \\
\hline $\begin{array}{r}1 \\
\text { RS } \\
\end{array}$ & $\begin{array}{l}\text { Fu11 replacement of Revision } 0 \text { with } \\
\text { Revision 1. Revision } 1 \text { issued via } \\
\text { ECN\#609902. }\end{array}$ & G. Ryan & $\begin{array}{l}\text { G. W. Gault } \\
7 j_{1 / 97} \text { sayeldeulto }\end{array}$ \\
\hline & & & \\
\hline & & & \\
\hline & & & \\
\hline & & & \\
\hline & & & \\
\hline & & & \\
\hline & & & \\
\hline & & & \\
\hline & & & \\
\hline & & & \\
\hline & & & \\
\hline & & & \\
\hline & & & \\
\hline & & & \\
\hline & & & \\
\hline & & & \\
\hline & & & \\
\hline & & & \\
\hline & & & \\
\hline & & & \\
\hline & & & \\
\hline & & & \\
\hline & & & \\
\hline & & & \\
\hline & & & \\
\hline & & & \\
\hline
\end{tabular}


HNF-SD-WM-CN-112 REV 1

EFFECTS OF A SPRAY LEAK INSIDE THE UNLOADING AREA

OF THE 204-AR WASTE UNLOADING FACILITY

REVISION 1

TWRS Safety Analysis

June 1997

1 of 34 
HNF-SD-WM-CN-112 REV 1

This page intentionally left blank. 
1.0 INTRODUCTION AND PURPOSE ..................... 7 of 34

2.0 SCOPE . . . . . . . . . . . . . . 9 of 34

3.0 METHODOLOGY, ASSUMPTIONS, AND INPUT DATA ........ 11 of 34

3.1 UNLOADING AREA DOOR CONFIGURATION ........... 11 of 34

3.2 VENTILATION SYSTEM OPERATION . . . . . . . . . . . 11 of 34

3.3 SOURCE TERM SELECTION ...................... 11 of 34

3.4 VOLUMETRIC AEROSOL RELEASE RATE .......... . 12 of 34

3.5 ATMOSPHERIC DISPERSION COEFFICIENTS . . . . . . . 13 of 34

3.6 METHOD OF DOSE CALCULATIONS ............ 14 of 34

3.7 UNIT AIR RELEASE RATE DOSE CALCULATIONS . . . . . . 15 of 34

3.8 VOLUMETRIC AIR OUTFLOW RATE . . . . . . . . . . 16 of 34

4.0 DOSE CONSEQUENCE CALCULATIONS .............. 19 of 34

4.1 RADIOLOGICAL DOSE CONSEQUENCES ............ . 19 of 34

4.2 TOXICOLOGICAL EXPOSURE CONSEQUENCES .......... 21 of 34

5.0 RESULTS AND CONCLUSIONS . . . . . . . . . . . 23 of 34

5.1 SUMMARY OF RESULTS . . . . . . . . . . . . . . . 23 of 34

5.2 CONCLUSIONS . . . . . . . . . 23 of 34

5.3 SENSITIVITY OF CONCLUSIONS TO ANALYSIS ASSUMPTIONS . . . 24 of 34

6.0 REFERENCES . . . . . . . . . . . . . . . 25 of 34

\section{APPENDICES}

A UNLOADING AREA DOOR CONFIGURATION ............ 27 of 34

B PEER REVIEW AND HEDOP REVIEW CHECKLISTS . . . . . . . 31 of 34 


\section{HNF-SD-WM-CN-112 REV 1}

\section{LIST OF TABLES}

1. Unit Liter Doses (ULD) for DST and AWF Liquids . . . . . . . . . . 12 of 34

2. Unit Release Rate Toxicological Sum of Fractions for DST Liquids for an Anticipated Accident Frequency with Deposition Effects............... 12 of 34

3. Atmospheric Dispersion Coefficients $\left(x / Q^{\prime} s\right)$ With Deposition Effects................... 14 of 34

4. Summary of Consequences and Frequencies of a Spray Leak Inside the Unloading Area of the 204-AR Waste Unloading Facility............ . 23 of 34 


\section{LIST OF TERMS}

$\begin{array}{ll}\text { AWF } & \text { aging waste facility } \\ \text { BI0 } & \text { basis for interim operation } \\ \text { CEDE } & \text { committed effective dose equivalent } \\ \text { DST } & \text { double shell tank } \\ \text { FSAR } & \text { final safety analysis report } \\ \text { HEDOP } & \text { Hanford Environmental Dose Overview Pane1 } \\ \text { rem } & \text { radiation effective man } \\ \text { SST } & \text { single-she11 tank } \\ \text { SV } & \text { sievert } \\ \text { TEDE } & \text { total effective dose equivalent } \\ \text { TWRS } & \text { Tank Waste Remediation System } \\ \text { ULD } & \text { unit liter dose } \\ \text { WHC } & \text { Westinghouse Hanford Company }\end{array}$


HNF-SD-WM-CN-112 REV 1

This page intentionally left blank. 


\section{EFFECTS OF A SPRAY LEAK INSIDE THE UNLOADING AREA OF THE 204-AR WASTE UNLOADING FACILITY}

\subsection{INTRODUCTION AND PURPOSE}

The purpose of this calculation note is to investigate the consequences associated with a spray leak of waste inside the unloading area of the 204-AR Waste Unloading Facility while all doors leading to the unloading area are open. A postulated misrouting of waste to the 204-AR Waste Unloading Facility is assumed to initiate a spray leak at one of transfer pump gaskets or in the short section of abovegrade piping that is located in the east end of the unloading area.

The 204-AR Waste Unloading Facility receives liquid radioactive waste shipments by railcar or tank trailer for transfer to the tank farms. The 204-AR Waste Unloading Facility is intended for one-way transfers (i.e., out of the facility) and is not designed to accept tank farm waste transfers through piping that is directly connected to the facility. The Tank Waste Remediation System Basis for Interim 0peration (HNF-SD-WM-BI0-001) includes a complete description of the 204-AR Waste Unloading Facility and associated operations.

The analysis performed and documented in this calculation note is intended to supplement the analys is documented in WHC-SD-WM-CN-048 and HNF-SD-WM-CN-096 and will be used to support conclusions drawn regarding the selection of controls to mitigate spray leak accidents. While spray leaks could also occur in the short section of piping that is pressurized during transfers from the 204-AR Waste Unloading Facility, they are considered to be bounded by the analys is that is performed here since it is likely that there would be greater monitoring (i.e., operator presence) and controls in place while railcar and tank trailer transfer operations are occurring. The analysis performed here is designed to cover situations when a misroute may occur and the facility is not manned. 
HNF-SD-WM-CN-112 REV 1

This page intentionally left blank. 


\subsection{SCOPE}

The scope of work is to assess the radiological dose and toxicological exposure consequences associated with a spray leak of waste inside the unloading area of the 204-AR Waste Unloading Facility while all doors leading the unloading area are open. Consistent with calculation notes WHC-SD-WM-CN-048 and HNF-SD-WM-CN-096, the radiological dose consequences wi11 be compared to the Revision 1 risk guidelines defined in WHC-CM-4-46 for an accident frequency of anticipated. Toxicological consequences are developed using the methodology defined in WHC-SD-WM-SARR-011, aTso assuming an accident frequency of anticipated. 
HNF-SD-WM-CN-112 REV 1

This page intentionally left blank. 


\subsection{METHODOLOGY, ASSUMPTIONS, AND INPUT DATA}

\subsection{UNLOADING AREA DOOR CONFIGURATION}

There are two sets of doors that lead to the unloading area. One set consists of the exterior roll-up door and folding doors that provide passage to the ratlcars and tank trailers on the west side of the 204-AR Waste Unloading Facility. The dimensions of the exterior roll-up door are $3.7 \mathrm{~m} \times 5.5 \mathrm{~m}$ (12 ft $\times 18 \mathrm{ft}$ ).

The other set of doors leading to the unloading area, also on the west side of the building, provide access for personnel. The two personnel access doors on the first floor are in place to create an airlock, minimizing the spread of contamination. The dimensions of the exterior personnel access door are $0.9 \mathrm{~m} \times 2.1 \mathrm{~m}(3 \mathrm{ft} \times 7 \mathrm{ft})$.

A11 door dimensions were provided by tank farm operations personnel for use in this analysis. A graphical depiction of the doors providing access to the unloading area are shown in Appendix A.

The analysis assumes that both sets of doors could be open (either together or independently) and discussion is based on the dimensions of the exterior doors. It is noted however, that if the inner doors (i.e., unloading area folding doors and the personnel access door) are open without the exterior unloading area roli-up door and exterior personnel access door being open, the unloading area atmosphere is still confined.

The other exterior doors on the 204-AR Waste Unloading Facility; the main entrance door on the east side and the mechanical equipment room doors on the north side do not provide direct access to the unloading area. These doors, therefore, are not addressed in this analysis.

\subsection{VENTILATION SYSTEM OPERATION}

The 204-AR Waste Unloading Facility ventilation system is assumed to not be operating (i.e., shutdown). This maximizes the amount of the contamination released from the unloading area since the ventilation system (with HEPA filters installed) would provide a mitigative effect to the spray leak accident.

\subsection{SOURCE TERM SELECTION}

The source term that is assumed to be released in this spray leak accident is assumed to be made up of double-shell tank (DST) liquids based on the rationale provided below.

Consistent with the analysis in both calculation notes WHC-SD-WM-CN-048 and HNF-SD-WM-CN-096 for a spray leak without controls, the misrouted waste is assumed to be made up of a slurry of aging waste facility (AWF) liquids and AWF liquids. In the case of the spray leak inside the 204-AR Waste Unloading Facility, the waste is assumed to deadhead at the transfer pump inside the unloading area. This would create a situation where the velocity of the waste approaching the leak point would be very slow allowing any solids present to 
settle in the transfer line or not even be removed from the sending tank (since the flow would be minimal). Therefore, the material leaked from the transfer 7 ine is assumed to be up of only AWF liquids. This assumption is considered reasonable based on the information provided and the results documented in HNF-SD-WM-CN-096 investigating the effects of solids loading in the aerosol release. The determination was made in HNF-SD-WM-CN-096 that the overall dose consequences are only weakly dependent on the amount of solids when deposition is considered.

Since onty liquids are being considered in the spray release, it should be noted that DST liquids have a higher inhalation unit liter dose (ULD) by approximately a factor of 4.4. Given this fact, DST 1iquids will be used in the calculation of dose consequences in this calculation note. Using DST liquids would also compensate for a small amount of solids in the source term, if present, and would also cover a mistransfer of DST 1iquids to the 204-AR Waste Unloading Facility. Calculations demonstrate that the ingestion component of offsite doses are relatively minor when compared to the total offsite dose consequences (inhalation and ingestion).

The ULDS for both DST and AWF 1 iquids developed in WHC-SD-WM-SARR-037 are shown in Table 1 .

Table 1. Unit Liter Doses (ULD) for DST and AWF Liquids.

\begin{tabular}{|c|c|c|}
\hline Waste Component & $\begin{array}{c}\text { Inhalation ULD } \\
(\mathrm{SV} / \mathrm{L})\end{array}$ & $\begin{array}{c}\text { Ingestjon ULD } \\
\left(\mathrm{SV}-\mathrm{m}^{3} / \mathrm{s}-\mathrm{L}\right)\end{array}$ \\
\hline DST Liquids & $6.1 \mathrm{E}+03$ & $6.8 \mathrm{E}-02$ \\
\hline AWF Liquids & $1.4 \mathrm{E}+03$ & $9.2 \mathrm{E}-02$ \\
\hline
\end{tabular}

To calculate the toxicological consequences in Section 4.2 , the following sum of fraction values presented in Table 2 are utilized.

Table 2. Unit Release Rate Toxicological Sum of Fractions for DST Liquids for an Anticipated Accident Frequency with Deposition Effects.

(from HNF-SD-WM-CN-096)

\begin{tabular}{|c|c|c|}
\hline Receptor & Waste Component & $\begin{array}{c}\text { Sum of Fractions (s/L) } \\
\text { With Deposition }\end{array}$ \\
\hline Onsite & DST/AWF Liquids & $8.5 \mathrm{E}+03$ \\
\hline Offsite & DST/AWF Liquids & $4.8 \mathrm{E}+00$ \\
\hline
\end{tabular}

${ }^{1}$ In WHC-SD-WM-SARR-011 no toxicological distinction is made between the AWF and DST waste types.

\subsection{VOLUMETRIC AEROSOL RELEASE RATE}

For convenience and for ease of computations, first a unit volumetric aerosol release rate of air from the open doorways is developed for use in the dose 


\section{HNF-SD-WM-CN-112 REV 1}

calculations. Then the actual outflow (calculated in Section 3.8) will be used to calculate the dose consequences to the onsite and offsite receptors.

A unit volumetric air outflow rate is defined as:

$$
\text { Volumetric air outflow rate }=1 \mathrm{~m}^{3} / \mathrm{s}
$$

The maximum aerosol loading of air under relatively quiescent non-transient conditions is $100 \mathrm{mg} / \mathrm{m}^{3}$ (ANSI 1980). Thus, the aerosol release rate for a unit volumetric air outflow rate is defined as follows:

Aerosol release rate $=$ (aerosol concentration) $x$ (volumetric air outflow rate)

$$
\begin{gathered}
=0.1 \mathrm{~g} / \mathrm{m}^{3} \times 1 \mathrm{~m}^{3} / \mathrm{s} \\
=0.1 \mathrm{~g} / \mathrm{s}
\end{gathered}
$$

The above calculation shows that the aerosol release rate for the volumetric air outflow rate of $1 \mathrm{~m}^{3} / \mathrm{s}$ is $0.1 \mathrm{~g} / \mathrm{s}$.

Considering DST 7iquids only (as discussed in Section 3.3), and assume that the density of the liquid is $1.1 \mathrm{~g} / \mathrm{cm}^{3}$ (WHC-SD-WM-SARR-011), then the volumetric aerosol release rate from the spray leak is:

$$
\begin{aligned}
\text { Volumetric aerosol } & \text { release rate }=0.1(\mathrm{~g} / \mathrm{s}) / 1.1\left(\mathrm{~g} / \mathrm{cm}^{3}\right) \\
& =9.09 \times 10^{-2} \mathrm{~cm}^{3} / \mathrm{s} \\
& =9.09 \times 10^{-5} \mathrm{~L} / \mathrm{s} . \\
& =3.27 \times 10^{-1} \mathrm{~L} / \mathrm{hr}
\end{aligned}
$$

This (i.e., $3.27 \times 10^{-1} \mathrm{~L} / \mathrm{hr}$ ) is the volumetric aerosol release rate from the facility per unit volumetric air outflow rate.

\subsection{ATMOSPHERIC DISPERSION COEFFICIENTS}

The atmospheric dispersion coefficients $x / Q$ 's for use in calculating the consequences to the onsite and offsite receptors for the release durations of $1 \mathrm{hr}, 12 \mathrm{hr}$ and $24 \mathrm{hr}$ from a location within the tank farms are shown in Table 3 . The effect of particle deposition has been taken into account in the calculations of $X / Q$ 's as shown in Table 3 . 
Table 3. Atmospheric Dispersion Coefficients $\left(X / Q^{\prime} s\right)$ With Deposition Effects. (from HNF-SD-WM-CN-096)

\begin{tabular}{|c|c|c|}
\hline \multirow{2}{*}{ Receptor } & Release Duration & $\begin{array}{c}x / Q \text { with deposition } \\
\left(\mathrm{s} / \mathrm{m}^{3}\right)\end{array}$ \\
\hline \multirow{3}{*}{ Onsite } & $1 \mathrm{hr}$ & $2.91 \mathrm{E}-02$ \\
\cline { 2 - 3 } & $12 \mathrm{hr}$ & $5.15 \mathrm{E}-03$ \\
\hline \multirow{2}{*}{ offsite } & $1 \mathrm{hr}$ & $1.61 \mathrm{E}-05$ \\
\cline { 2 - 3 } & $24 \mathrm{hr}$ & $2.75 \mathrm{E}-06$ \\
\hline
\end{tabular}

\subsection{METHOD OF DOSE CALCULATIONS}

Given an airborne source term, the doses from the inhalation and ingestion pathways are calculated using the following formulas (from WHC-SD-WM-SARR-016) :

Inhalation:

$$
\mathrm{D}_{\mathrm{inh}}(S V)=Q(L) \times \frac{x}{Q^{\prime}}\left(\frac{s}{m^{3}}\right) \times R\left(\frac{m^{3}}{\mathrm{~s}}\right) \times U L D_{\mathrm{inh}}\left(\frac{S V}{L}\right)
$$

Ingestion:

$$
D_{\text {ing }}(S v)=Q(L) \times \frac{x}{Q^{\prime}}\left(\frac{s}{m^{3}}\right) \times U L D_{\text {ing }}\left(\frac{s v-m^{3}}{s-L}\right)
$$

where

$$
\begin{aligned}
& D_{\text {inh }}=\text { dose due to inhalation (Sv) } \\
& \mathrm{D}_{\text {ing }}=\text { dose due to ingestion (Sv) } \\
& Q=\text { respirable source term }(L) \\
& X / Q^{\prime}=\underset{T a b l e ~ 3)}{\text { appropriate atmospheric dispersion coefficient }\left(\mathrm{s} / \mathrm{m}^{3}\right) \text { (from }} \\
& \mathrm{R}=\text { breathing rate }\left(3.3 \times 10^{-4} \mathrm{~m}^{3} / \mathrm{s}\right. \text { - acute breathing rate } \\
& 2.7 \times 10^{-4} \mathrm{~m}^{3} / \mathrm{s} \text { - chronic [24 hr]) } \\
& \mathrm{ULD}_{\text {inh }}=\text { inhalation unit liter dose }(\mathrm{SV} / \mathrm{L} \text {, see Table } 1) \\
& U L D_{\text {ing }}=\text { ingestion unit liter dose }\left(S v-m^{3} / s-L \text {, see Table } 1\right) \text {. }
\end{aligned}
$$


For the inhalation pathway, the dose calculated is the 50-year committed effective dose equivalent (CEDE) defined as the dose received by the individual during a 50-year period following the uptake. For the maximum onsite individual, this dose must be combined with that due to external exposure (if any) to yield the TEDE. For the ingestion pathway, the dose calculated is the CEDE from ingestion plus the dose due to external exposure (e.g., ground shine) during the first 24 hours after the release. Combining the ingestion dose with the inhalation dose yields the TEDE for the maximum offsite individual.

\subsection{UNIT AIR RELEASE RATE DOSE CALCULATIONS}

Using $X / Q$ values (from Table 3) for the onsite receptor for durations of 1 and 12 hours and the inhalation unit liter dose for DST Tiquids of $6.1 \times 10^{3} \mathrm{SV} / \mathrm{L}$ (Table 1), unit radiological doses can be calculated for the onsite receptor as follows:

a. Onsite

1-hr release:

$$
\begin{aligned}
D_{\text {inh }}= & \left(3.27 \times 10^{-1} \mathrm{~L} / \mathrm{hr} \times 1 \mathrm{hr}\right)\left(2.91 \times 10^{-2} \mathrm{~s} / \mathrm{m}^{3}\right)\left(3.3 \times 10^{-4} \mathrm{~m}^{3} / \mathrm{s}\right) \\
& \left(6.1 \times 10^{3} \mathrm{~Sv} / \mathrm{L}\right) \\
= & 1.92 \times 10^{-2} \mathrm{~Sv}(1.92 \mathrm{rem})
\end{aligned}
$$

12-hour release:

$$
\begin{aligned}
D_{i n h}= & \left(3.27 \times 10^{-1} \mathrm{~L} / \mathrm{hr} \times 12 \mathrm{hr}\right)\left(5.15 \times 10^{-3} \mathrm{~s} / \mathrm{m}^{3}\right)\left(3.3 \times 10^{-4} \mathrm{~m}^{3} / \mathrm{s}\right) \\
& \left(6.1 \times 10^{3} \mathrm{~Sv} / \mathrm{L}\right) \\
= & 4.07 \times 10^{-2} \mathrm{~Sv}(4.07 \mathrm{rem})
\end{aligned}
$$

In the above dose calculations, the volumetric air outflow rate of $1 \mathrm{~m}^{3} / \mathrm{s}$ is assumed (see discussion in Section 3.4).

b. Offsite

Using $x / Q$ values (from Table 3 ) for the offsite receptor, the inhalation unit liter dose for DST liquids of $5.1 \times 10^{3} \mathrm{~Sv} / \mathrm{L}$ and the ingestion unit liter dose of $6.8 \times 10^{-2} \mathrm{~Sv}-\mathrm{m}^{3} / \mathrm{s}-\mathrm{L}$ (Table 1 ), unit radiological doses can be calculated for the offsite receptor as follows:

1-hr release:

$$
\begin{aligned}
D_{\text {inh }}= & \quad\left(3.27 \times 10^{-1} \mathrm{~L} / \mathrm{hr} \times 1 \mathrm{hr}\right)\left(1.61 \times 10^{-5} \mathrm{~s} / \mathrm{m}^{3}\right)\left(3.3 \times 10^{-4} \mathrm{~m}^{3} / \mathrm{s}\right) \\
& \left(6.1 \times 10^{3} \mathrm{~Sv} / \mathrm{L}\right) \\
= & 1.06 \times 10^{-5} \mathrm{~Sv}\left(1.06 \times 10^{-3} \mathrm{rem}\right) \\
D_{\text {ing }}= & \left(3.27 \times 10^{-1} \mathrm{~L} / \mathrm{hr} \times 1 \mathrm{hr}\right)\left(1.61 \times 10^{-5} \mathrm{~s} / \mathrm{m}^{3}\right)\left(6.8 \times 10^{-2} \mathrm{~Sv}-\mathrm{m}^{3} / \mathrm{s}-\mathrm{L}\right) \\
= & 3.58 \times 10^{-7} \mathrm{~Sv}\left(3.58 \times 10^{-5} \mathrm{rem}\right)
\end{aligned}
$$


24-hr release:

$$
\begin{aligned}
D_{\text {inh }}= & \begin{array}{l}
\left(3.27 \times 10^{-1} \mathrm{~L} / \mathrm{hr} \times 24 \mathrm{hr}\right)\left(2.75 \times 10^{-6} \mathrm{~s} / \mathrm{m}^{3}\right)\left(2.7 \times 10^{-4} \mathrm{~m}^{3} / \mathrm{s}\right) \\
\left(6.1 \times 10^{3} \mathrm{~Sv} / \mathrm{L}\right)
\end{array} \\
= & 3.55 \times 10^{-5} \mathrm{SV}\left(3.55 \times 10^{-3} \mathrm{rem}\right) \\
D_{\text {ing }}= & \left(3.27 \times 10^{-1} \mathrm{~L} / \mathrm{hr} \times 24 \mathrm{hr}\right)\left(2.75 \times 10^{-6} \mathrm{~s} / \mathrm{m}^{3}\right)\left(6.8 \times 10^{-2} \mathrm{sv}-\mathrm{m}^{3} / \mathrm{s}-\mathrm{L}\right) \\
= & 1.47 \times 10^{-6} \mathrm{~Sv}\left(1.47 \times 10^{-4} \mathrm{rem}\right)
\end{aligned}
$$

In the above dose calculations, the volumetric air outflow rate of $1 \mathrm{~m}^{3} / \mathrm{s}$ is assumed (see discussion in Section 3.4).

\subsection{VOLUMETRIC AIR OUTFLOW RATE}

It is assumed that the wind is blowing against the west side of the 204-AR Waste Unloading Facility at a speed $v=1 \mathrm{~m} / \mathrm{s}$ at a 45 degree angle from the plane of the doorways. It should be noted here that the results for the calculated doses are not highly sensitive to the wind speed because the increase in the wind speed will increase the amount of aerosol release but decrease the atmospheric dispersion coefficient $(X / Q)$ by the same proportion.

The calculation of the volumetric air outflow rate for the open roll-up doorway and open personnel access doorway will be performed separately.

Ro17-up Doorway:

The area of the roll-up doorway is:

$$
\begin{aligned}
\text { Area } & =3.7 \mathrm{~m} \times 5.5 \mathrm{~m} \\
& =20.35 \mathrm{~m}^{2}
\end{aligned}
$$

Thus, the area of the rol1-up doorway facing directly to the wind is:

$$
\begin{gathered}
\text { Area }=(\text { area of the doorway })(\sin (\pi / 4)) \\
=20.35 \mathrm{~m}^{2} \times 0.707 \\
=14.38 \mathrm{~m}^{2}
\end{gathered}
$$

Based on the mass balance (the continuity of the mass), the inflow is equal to the outflow. Thus, the volumetric air outflow rate through the projected area of $14.38 \mathrm{~m}^{2}$ of the door opening is:

$$
\begin{gathered}
\text { Volumetric air outflow rate }=(\text { wind speed) }(\text { area }) / 2 \\
=1 \mathrm{~m} / \mathrm{s} \times 14.38 \mathrm{~m}^{2} / 2 \\
=7.19 \mathrm{~m}^{3} / \mathrm{s}
\end{gathered}
$$

The above calculated volumetric air outflow rate of $7.19 \mathrm{~m}^{3} / \mathrm{s}$ is an upper bound. This is the maximum efficiency of air exchange rate. If it is assumed that the wind blows toward the doorway from the right hand side (i.e., 
southeastern direction), the air circulation inside the unloading area will be in the clockwise direction. This clockwise air current will push the air out of the building to the outside in the opposite direction of the inflow through the open roll-up doors.

The efficiency factor for the air outflow due to the process of air mixing could be as high as $50 \%$ because of the generation of eddies and the vortex inside the building. Assuming that the efficiency factor of the air mixing is 50 percent, then the effective volumetric outflow rate of air fully loaded with aerosol is:

$$
\begin{gathered}
\text { Volumetric air outflow rate }=7.19 \mathrm{~m}^{3} / \mathrm{s} \times 0.5 \\
=3.60 \mathrm{~m}^{3} / \mathrm{s}
\end{gathered}
$$

Personnel Access Doorway:

Similarly, the area of the personnel access doorway is:

$$
\begin{aligned}
\text { Area } & =0.9 \mathrm{~m} \times 2.1 \mathrm{~m} \\
& =1.89 \mathrm{~m}^{2}
\end{aligned}
$$

Thus, the area of the personnel doorway facing directly to the wind is:

$$
\begin{gathered}
\text { Area }=(\text { area of the doorway })(\sin (n / 4)) \\
=1.89 \mathrm{~m}^{2} \times 0.707 \\
=1.34 \mathrm{~m}^{2}
\end{gathered}
$$

Based on the mass balance (the continuity of the mass), the inflow is equal to the outflow. Thus, the volumetric air outflow rate through the projected area of $1.34 \mathrm{~m}^{2}$ of the door opening is:

$$
\begin{aligned}
& \text { Volumetric air outflow rate }=\text { (wind speed) }(\text { area }) / 2 \\
& =1 \mathrm{~m} / \mathrm{s} \times 1.34 \mathrm{~m}^{2} / 2 \\
& =0.67 \mathrm{~m}^{3} / \mathrm{s}
\end{aligned}
$$

The above calculated volumetric air outflow rate of $0.67 \mathrm{~m}^{3} / \mathrm{s}$ is an upper bound. This is the maximum efficiency of air exchange rate. If it is assumed that the wind blows toward the doorway from the right hand side (i.e., southeastern direction), the air circulation inside the airlock will be in the clockwise direction. This clockwise air current will push the air out of the building to the outside in the opposite direction of the inflow through the open personnel access doors.

The efficiency factor for the air outflow due to the process of air mixing could be as high as $50 \%$ because of the generation of eddies and the vortex inside the building. Assuming that the efficiency factor of the air mixing is 


\section{HNF-SD-WM-CN-112 REV 1}

50 percent, then the effective volumetric outflow rate of air fully loaded with aerosol is:

$$
\begin{gathered}
\text { Volumetric air outflow rate }=0.67 \mathrm{~m}^{3} / \mathrm{s} \times 0.5 \\
=0.34 \mathrm{~m}^{3} / \mathrm{s}
\end{gathered}
$$

The volumetric outflow rates calculated here for both the roll-up and personnel access doorways have been analyzed separately to allow determination of the dose consequences from each door being open. This will allow the user of this document to evaluate the consequences of a spray leak inside the unloading area when either door or both doors are open. 
HNF-SD-WM-CN-112 REV 1

\subsection{DOSE CONSEQUENCE CALCULATIONS}

\subsection{RADIOLOGICAL DOSE CONSEQUENCES}

The radiological dose consequences are calculated separately for each of the open doorways.

Ro17-up Doorway:

Using the actual outflow rate of $3.60 \mathrm{~m}^{3} / \mathrm{s}$ calculated in Section 3.8 , the radiological dose consequences are calculated in the following manner:

a. Onsite

1-hour release:

$$
\begin{aligned}
D_{\text {inh }} & =1.92 \times 10^{-2}\left(\mathrm{~Sv} / \mathrm{m}^{3} / \mathrm{s}\right) \times 3.60\left(\mathrm{~m}^{3} / \mathrm{s}\right) \\
& =6.91 \times 10^{-2} \mathrm{~Sv}(6.91) \text { rem }
\end{aligned}
$$

12-hour release:

$$
\begin{aligned}
D_{\text {inh }} & =4.07 \times 10^{-2}\left(\mathrm{~Sv} / \mathrm{m}^{3} / \mathrm{s}\right) \times 3.60\left(\mathrm{~m}^{3} / \mathrm{s}\right) \\
& =1.47 \times 10^{-1} \mathrm{~Sv}\left(1.47 \times 10^{1} \mathrm{rem}\right)
\end{aligned}
$$

b. Offsite

1-hour release:

$$
\begin{aligned}
D_{\text {inh }} & =1.06 \times 10^{-5}\left(\mathrm{~Sv} / \mathrm{m}^{3} / \mathrm{s}\right) \times 3.60\left(\mathrm{~m}^{3} / \mathrm{s}\right) \\
& =3.82 \times 10^{-5} \mathrm{~Sv}\left(3.82 \times 10^{-3} \mathrm{rem}\right) \\
D_{\text {ing }} & =3.58 \times 10^{-7}\left(\mathrm{~Sv} / \mathrm{m}^{3} / \mathrm{s}\right) \times 3.60\left(\mathrm{~m}^{3} / \mathrm{s}\right) \\
& =1.29 \times 10^{-6} \mathrm{SV}\left(1.29 \times 10^{-4} \mathrm{rem}\right) \\
D_{\text {total }} & =D_{\text {inh }}+D_{\text {ing }} \\
& =3.82 \times 10^{-5} \mathrm{~Sv}+1.29 \times 10^{-6} \mathrm{~Sv} \\
& =3.95 \times 10^{-5} \mathrm{~Sv}\left(3.95 \times 10^{-3} \mathrm{rem}\right)
\end{aligned}
$$

24-hour release:

$$
\begin{aligned}
D_{\text {inh }} & =3.55 \times 10^{-5}\left(\mathrm{~Sv} / \mathrm{m}^{3} / \mathrm{s}\right) \times 3.60\left(\mathrm{~m}^{3} / \mathrm{s}\right) \\
& =1.28 \times 10^{-4} \mathrm{~Sv}\left(1.28 \times 10^{-2} \mathrm{rem}\right) \\
D_{\text {ing }} & =1.47 \times 10^{-6}\left(\mathrm{~Sv} / \mathrm{m}^{3} / \mathrm{s}\right) \times 3.60\left(\mathrm{~m}^{3} / \mathrm{s}\right) \\
& =5.29 \times 10^{-6} \mathrm{~Sv}\left(5.29 \times 10^{-4} \mathrm{rem}\right)
\end{aligned}
$$




$$
\begin{aligned}
D_{\text {total }} & =D_{\text {inh }}+D_{\text {ing }} \\
& =1.28 \times 10^{-4} \mathrm{~Sv}+5.29 \times 10^{-6} \mathrm{~Sv} \\
& =1.33 \times 10^{-4} \mathrm{~Sv}\left(1.33 \times 10^{-2} \mathrm{~Sv}\right)
\end{aligned}
$$

\section{Personnel Access Doorway:}

Using the actual outflow rate of $0.34 \mathrm{~m}^{3} / \mathrm{s}$ calculated in Section 3.8 , the radiological consequences are calculated in the following manner:

a. Onsite

1-hour release:

$$
\begin{aligned}
D_{i n h} & =1.92 \times 10^{-2}\left(5 v / m^{3} / \mathrm{s}\right) \times 0.34\left(\mathrm{~m}^{3} / \mathrm{s}\right) \\
& =6.53 \times 10^{-3} \mathrm{sv}\left(6.53 \times 10^{-1} \mathrm{rem}\right)
\end{aligned}
$$

12-hour release:

$$
\begin{aligned}
D_{i n h} & =4.07 \times 10^{-2}\left(\mathrm{~Sv} / \mathrm{m}^{3} / \mathrm{s}\right) \times 0.34\left(\mathrm{~m}^{3} / \mathrm{s}\right) \\
& =1.38 \times 10^{-2} \mathrm{~Sv}(1.38 \mathrm{rem})
\end{aligned}
$$

b. Offsite

1-hour release:

$$
\begin{aligned}
D_{i n h}= & 1.06 \times 10^{-5}\left(\mathrm{~Sv} / \mathrm{m}^{3} / \mathrm{s}\right) \times 0.34\left(\mathrm{~m}^{3} / \mathrm{s}\right) \\
= & 3.60 \times 10^{-6} \mathrm{~Sv}\left(3.60 \times 10^{-4} \mathrm{rem}\right) \\
D_{\text {ing }} & =3.58 \times 10^{-7}\left(\mathrm{~Sv} / \mathrm{m}^{3} / \mathrm{s}\right) \times 0.34\left(\mathrm{~m}^{3} / \mathrm{s}\right) \\
= & 1.22 \times 10^{-7} \mathrm{SV}\left(1.22 \times 10^{-5} \mathrm{rem}\right) \\
D_{\text {total }} & =D_{i n h}+D_{i n g} \\
& =3.60 \times 10^{-6} \mathrm{~Sv}+1.22 \times 10^{-7} \mathrm{~Sv} \\
& =3.72 \times 10^{-6} \mathrm{~Sv}\left(3.72 \times 10^{-4} \mathrm{rem}\right)
\end{aligned}
$$

24-hour release:

$$
\begin{aligned}
D_{\text {inh }} & =3.55 \times 10^{-5}\left(\mathrm{~Sv} / \mathrm{m}^{3} / \mathrm{s}\right) \times 0.34\left(\mathrm{~m}^{3} / \mathrm{s}\right) \\
& =1.21 \times 10^{-5} \mathrm{~Sv}\left(1.21 \times 10^{-3} \mathrm{rem}\right) \\
D_{\text {ing }} & =1.47 \times 10^{-6}\left(\mathrm{~Sv} / \mathrm{m}^{3} / \mathrm{s}\right) \times 0.34\left(\mathrm{~m}^{3} / \mathrm{s}\right) \\
& =5.00 \times 10^{-7} \mathrm{~Sv}\left(5.00 \times 10^{-5} \mathrm{rem}\right)
\end{aligned}
$$




$$
\begin{aligned}
D_{\text {total }} & =D_{\text {inh }}+D_{\text {ing }} \\
& =1.21 \times 10^{-5} \mathrm{~Sv}+5.00 \times 10^{-7} \mathrm{~Sv} \\
& =1.26 \times 10^{-5} \mathrm{~Sv}\left(1.26 \times 10^{-3} \mathrm{~Sv}\right)
\end{aligned}
$$

\subsection{TOXICOLOGICAL EXPOSURE CONSEQUENCES}

The toxicological exposure consequences are calculated separately for each of the open doorways.

The calculated toxicological sum of fractions is simply the appropriate unit release sum of fractions given in Table 2 times the respirable aerosol release rate $(Q)$.

\section{Roll-up Doorway:}

The respirable aerosol release rate (Q) from the roll-up doorway is:

$$
\begin{gathered}
Q=9.09 \times 10^{-5} \mathrm{~L} / \mathrm{s} \text { per } \mathrm{m}^{3} / \mathrm{s} \text { air flow } \times 3.60 \mathrm{~m}^{3} / \mathrm{s} \\
=3.27 \times 10^{-4} \mathrm{~L} / \mathrm{s}
\end{gathered}
$$

a. Onsite sum of fractions

$$
\begin{aligned}
\text { Sum of fractions } & =\left(8.5 \times 10^{3} \mathrm{~s} / \mathrm{L}\right)\left(3.27 \times 10^{-4} \mathrm{~L} / \mathrm{s}\right) \\
& =2.78
\end{aligned}
$$

b. Offsite sum of fractions

$$
\begin{aligned}
\text { Sum of fractions } & =(4.8 \mathrm{~s} / \mathrm{L})\left(3.27 \times 10^{-4} \mathrm{~L} / \mathrm{s}\right) \\
& =1.57 \times 10^{-3}
\end{aligned}
$$

\section{Personnel Access Doorway:}

The respirable aerosol release rate $(Q)$ from the roll-up doorway is:

$$
\begin{gathered}
Q=9.09 \times 10^{-5} \mathrm{~L} / \mathrm{s} \text { per m} \mathrm{m}^{3} / \mathrm{s} \text { air flow } \times 0.34 \mathrm{~m}^{3} / \mathrm{s} \\
=3.09 \times 10^{-5} \mathrm{~L} / \mathrm{s}
\end{gathered}
$$

a. Onsite sum of fractions

$$
\begin{aligned}
\text { Sum of fractions } & =\left(8.5 \times 10^{3} \mathrm{~s} / \mathrm{L}\right)\left(3.09 \times 10^{-5} \mathrm{~L} / \mathrm{s}\right) \\
& =2.63 \times 10^{-1}
\end{aligned}
$$

b. Offsite sum of fractions

$$
\begin{aligned}
\text { Sum of fractions } & =(4.8 \mathrm{~s} / \mathrm{L})\left(3.09 \times 10^{-5} \mathrm{~L} / \mathrm{s}\right) \\
& =1.48 \times 10^{-4} \\
& 21 \text { of } 34
\end{aligned}
$$


HNF-SD-WM-CN-112 REV 1

This page intentionally left blank. 


\subsection{RESULTS AND CONCLUSIONS}

\subsection{SUMMARY OF RESULTS}

The $12 \mathrm{hr}$ (onsite) and $24 \mathrm{hr}$ (offsite) release duration consequences that were calculated in Section 4.0 are presented in Table 4.

Table 4. Summary of Consequences and Frequencies of a Spray Leak Inside the Unloading Area of the 204-AR Waste Unloading Facility.

\begin{tabular}{|c|c|c|c|c|c|c|c|c|c|}
\hline \multirow{4}{*}{ Open Door ${ }^{1}$} & \multicolumn{8}{|c|}{ Consequences } & \multirow{4}{*}{$\begin{array}{l}\text { Frequency } \\
\text { Without } \\
\text { controls }\end{array}$} \\
\hline & \multicolumn{4}{|c|}{$\begin{array}{l}\text { Radiological } \\
\text { Sv (rem) }\end{array}$} & \multicolumn{4}{|c|}{$\begin{array}{l}\text { Toxicological } \\
\text { SOF }\end{array}$} & \\
\hline & \multicolumn{2}{|c|}{ Onsite } & \multicolumn{2}{|c|}{ Offsite } & \multicolumn{2}{|c|}{ Onsite } & \multicolumn{2}{|c|}{ Offsite } & \\
\hline & $\begin{array}{l}\text { Calculated } \\
\text { Dose }\end{array}$ & $\begin{array}{c}\text { Risk } \\
\text { Guideline }\end{array}$ & $\begin{array}{l}\text { Calculated } \\
\text { Dose }\end{array}$ & $\begin{array}{c}\text { Risk } \\
\text { Guideline }\end{array}$ & $\begin{array}{l}\text { Calculated } \\
\text { SoF }\end{array}$ & $\begin{array}{c}\text { Risk } \\
\text { Guideline }\end{array}$ & $\begin{array}{c}\text { Calculated } \\
\text { SoF }\end{array}$ & $\begin{array}{l}\text { Risk } \\
\text { Guideline }\end{array}$ & \\
\hline $\begin{array}{l}\text { Roll-up } \\
\text { Only }\end{array}$ & $\begin{array}{c}1.47 \mathrm{E}-01 \\
\{1.47 \mathrm{E}+011\end{array}$ & $\begin{array}{c}5.0 \mathrm{E}-03 \\
(5.0 \mathrm{E}-01)\end{array}$ & $\begin{array}{c}1.33 \mathrm{E}-04 \\
(1.33 \mathrm{E}-\mathrm{O} 2)\end{array}$ & $\begin{array}{c}1.0 \mathrm{E}-03 \\
(1.0 \mathrm{E}-01)\end{array}$ & $2.78 E+\infty 0$ & $\begin{array}{c}1 \\
\text { (ERPG-1) }\end{array}$ & $1.57 \mathrm{E}-03$ & $\frac{1}{\text { [PEL-TWA] }}$ & Anticipated \\
\hline $\begin{array}{c}\text { Personnel } \\
\text { Access } \\
\text { Only }\end{array}$ & $\begin{array}{c}1.38 E-02 \\
\{1.38 E+00\}\end{array}$ & $\begin{array}{c}5.0 \text { E-03 } \\
(5.0 \text { E-01) }\end{array}$ & $\begin{array}{c}1.26 \mathrm{E}-05 \\
(1.26 \mathrm{E}-03)\end{array}$ & $\begin{array}{c}1.0 \mathrm{E}-03 \\
(1.0 \mathrm{E}-01\}\end{array}$ & $2.63 \mathrm{E}-01$ & $\begin{array}{c}1 \\
\text { (ERPG-1) }\end{array}$ & $1.48 \mathrm{E}-04$ & $\begin{array}{c}1 \\
\text { (PEL-TWA) }\end{array}$ & Anticipated \\
\hline $\begin{array}{c}\text { Rolt-up and } \\
\text { Personnel } \\
\text { Access }\end{array}$ & $\left(\begin{array}{c}1.61 \mathrm{E}-01 \\
(1.61 \mathrm{E}+01)\end{array}\right)$ & $\begin{array}{l}5.0 \mathrm{E}-03 \\
\text { [5.0 E-01] }\end{array}$ & $\begin{array}{c}1.46 \mathrm{E}-04 \\
(1.46 \mathrm{E}-02)\end{array}$ & $\begin{array}{l}1.0 \mathrm{E}-03 \\
(1.0 \mathrm{E}-0)\end{array}$ & $3.04 E+00$ & $\begin{array}{c}3 \\
\text { (ERPG-1) }\end{array}$ & $1.72 \mathrm{E}-03$ & $\begin{array}{c}1 \\
\text { (PEL-TWA) }\end{array}$ & Anticipated \\
\hline \multicolumn{10}{|c|}{ 'For a detailed discussion of the doars listed see Section 3.1. } \\
\hline $\begin{array}{c}\text { ERPG } \\
\text { NA } \\
\text { PEL } \\
\text { SOF } \\
\text { TWA }\end{array}$ & $\begin{array}{l}=\text { Emergene } \\
=\text { not applic } \\
=\text { permissibt } \\
=\text { sum of fra } \\
=\text { time-weigl }\end{array}$ & $\begin{array}{l}\text { Response P } \\
\text { ble. } \\
\text { exposure lir } \\
\text { tions. } \\
\text { ted average. }\end{array}$ & inning Guideli & & & & & & \\
\hline
\end{tabular}

The results presented in Table 4 show that the onsite radiological dose consequences exceed the risk guideline for 1) the open roll-up door, 2) the open personnel access door, and 3 ) both the doors being open. The offsite radiological dose consequences do not exceed the risk guideline when any of the doors are assumed open.

Similarly, Table 4 shows that the onsite toxicological exposure consequences exceed the risk guideline for the open roll-up door oniy. The offsite toxicological exposure consequences do not exceed the risk guideline when any of the doors are open.

\subsection{CONCLUSIONS}

The results of this analysis lead to the conclusion that the exterior rol1-up door and west exterior personnel access door must be closed during waste transfers physically connected to the 204-AR Waste Unloading Facility. With the doors closed, external winds will not be able to sweep through the unloading area or airlock, and the facility will be able to confine the aerosol generated by any potential spray leak in the unloading area.

This safety analysis does not conclude that it is necessary to have the inner doors leading to the unloading area closed, although other contamination control requirements may mandate closure. As discussed in Section 3.1., these 
doors are the folding doors to the unloading area and the inner personnel access door to the unloading area (also see Appendix A for the location of the doors). The closed exterior unloading area and personnel access doors alone will suffice to keep the wind out of the unloading area.

\subsection{SENSITIVITY OF CONCLUSIONS TO ANALYSIS ASSUMPTIONS}

It should be noted that changing analysis assumptions such as the wind speed of $1 \mathrm{~m} / \mathrm{s}$, the direction of wind speed at a 45 degree angle from the $\mathrm{plane}$ of the doorways, or the efficiency factor of 0.5 for the air outflow due to the process of air mixing, will have no impact on the conclusions drawn from this analysis. 
HNF-SD-WM-CN-112 REV 1

\subsection{REFERENCES}

ANSI N46. 1 1980, American National Standard - Guidance for Defining Safety Related Features of Nuclear Fuel Cycle Facilities, American Nuclear Society, La Grange Park, Illinois.

HNF-SD-WM-BI0-001, 1997, Tank Waste Remediation System Basis for Interim operation, Rev. 0, Fluor Daniel Hanford, Richland, Washington.

HNF-SD-WM-CN-096, 1997, Refined Radiological and Toxicological Consequences of Bounding Spray Leak Accidents in Tank Farm Waste Transfer Pits, Rev. 0-A, Fluor Daniel Hanford, Richland, Washington.

WHC-SD-WM-CN-048, 1996, Calculation Notes in Support of TWRS FSAR Spray Leak Accident Analysis, Rev. 1, Westinghouse Hanford Company, Richland, Washington.

WHC-SD-WM-SARR-011, 1996, Toxic Chemical Considerations for Tank Farm Releases, Rev. 2, Westinghouse Hanford Company, Richland, Washington.

WHC-SD-WM-SARR-016, 1996, Tank Waste Compositions and Atmospheric Dispersion Coefficients for Use in Safety Analysis Consequence Assessments, Rev. 2, Westinghouse Hanford Company, Richland, Washington.

WHC-SD-WM-SARR-037, 1996, Development of Radiological Concentrations and Unit Liter Doses for Tank Waste Remediation System Final Safety Analysis Report Radiological Consequence Calculations, Rev. 0, Westinghouse Hanford Company, Richland, Washington. 
HNF-SD-WM-CN-112 REV 1

This page intentionally left blank. 
HNF-SD-WM-CN-112 REV 1

APPENDIX A

UNLOADING AREA DOOR CONFIGURATION

27 of 34 
HNF-SD-WM-CN-112 REV 1

This page intentionally left blank. 


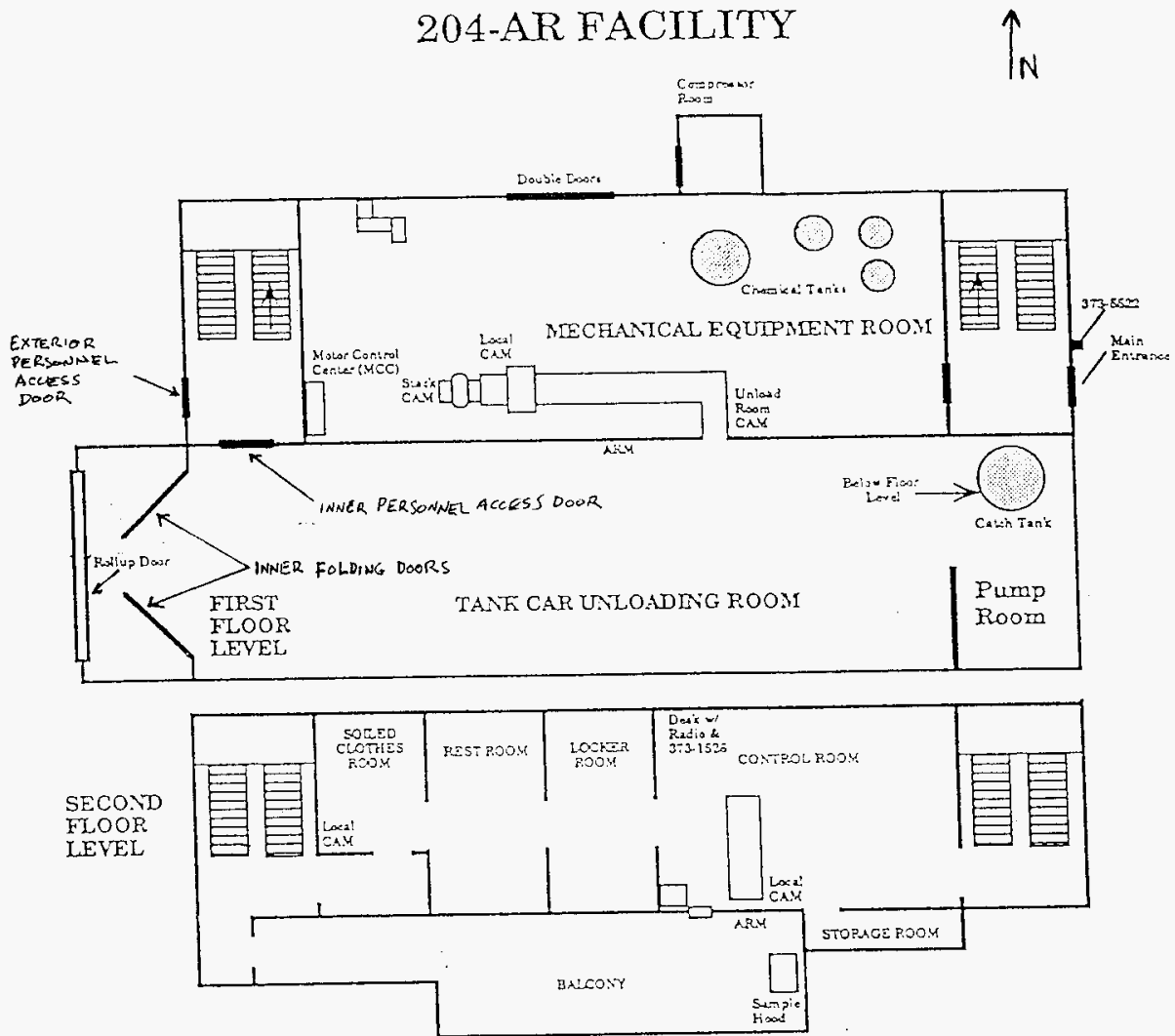


HNF-SD-WM-CN-112 REV 1

This page intentionally left blank. 
HNF-SD-WM-CN-112 REV 1

APPENDIX B

PEER REVIEW AND HEDOP REVIEW CHECKLISTS

31 of 34 
HNF-SD-WM-CN-112 REV 1

This page intentionally left blank. 


\section{CHECKLIST FOR PEER REVIEW}

Document Reviewed: HNF-SD-WM-CN-112, Revision 1, Effects of a Spray Leak Inside the Unloading Area of the 204-AR Waste Unloading Facility.

Scope of Review: Entire document

$\frac{\text { Yes No NA }}{[1] \text { [ ] }}$

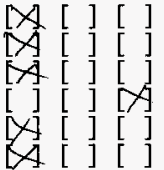

$凶[][]$

$\mathbb{A}[][]$

$M[$ [ [ ]

[][]$[X]$

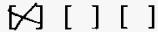

过 [ ] [ [ ] ]

$凶[$ ] [ ]

[ ] [ ] $\triangle$

[ ] $\ *$

Previous reviews complete and cover analysis, up to scope of this review, with no gaps.

Problem completely defined.

Accident scenarios developed in a clear and logical manner.

Necessary assumptions explicitly stated and supported.

Computer codes and data files documented.

Data used in calculations explicitly stated in document.

Data checked for consistency with original source information as applicable.

Mathematical derivations checked including dimensional consistency of results.

Models appropriate and used within range of validity or use outside range of established validity justified.

Hand calculations checked for errors. Spreadsheet results should be treated exactly the same as hand calculations.

Software input correct and consistent with document reviewed. Software output consistent with input and with results reported in document reviewed.

Limits/criteria/guidelines applied to analysis results are appropriate and referenced. Limits/criteria/guidelines checked against references.

Safety margins consistent with good engineering practices. Conclusions consistent with analytical results and applicable limits.

Results and conclusions address all points required in the problem statement.

Format consistent with appropriate NRC Regulatory Guide or other standards

Review calculations, comments, and/or notes are attached.

Document approved.

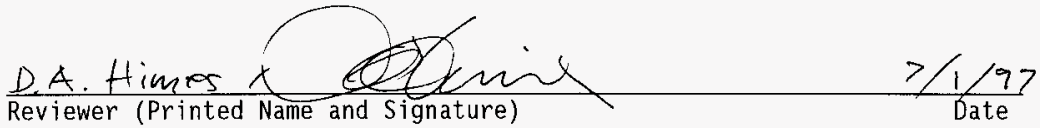

* Any calculations, comments, or notes generated as part of this review should be signed, dated and attached to this checklist. Such material should be labeled and recorded in such a manner as to be intelligible to a technically qualified third party. 


\section{HNF-SD-WM-CN-112 REV 1 \\ HEDOP REVIEW CHECKLIST \\ for \\ Radiological and Nonradiological Release Calculations}

Document reviewed (include title or description of calculation, document number, author, and date, as applicable):

HNF-SD-WM-CN-112, Revision 1, Effects of a Spray Leak Inside the Unloading Area of the 204-AR Waste Unloading Facility.

Submitted by: Grant W. Ryan

Date Submitted: June 25, 1997

Scope of Review: Entire document.

YES NO* N/A

[A [ ] [ ] 1. A detailed technical review and approval of the environmental transport and dose calculation portion of the analysis has been performed and documented.

ty [ ] [ ] 2. Detai]ed technical review(s) and approval(s) of scenario and release determinations have been performed and documented.

[ ] [ ] [4 3. HEDOP-approved code(s) were used.

[ ] [ ] 4. Receptor locations were selected according to HEDOP recommendations.

4 [ ] [ ] 5. All applicable environmental pathways and code options were included and are appropriate for the calculations.

[ [ ] [ ] 6. Hanford site data were used.

[ ] [ ] [4 7. Model adjustments external to the computer program were justified and performed correctly.

4 [ ] [ ] 8. The analysis is consistent with HEDOP recommendations.

[ ] 9. Supporting notes, calculations, comments, comment resolutions, or other information is attached. (Use the "Page 1 of $X$ " page numbering format and sign and date each added page.)

[\] [ 10. Approval is granted on behalf of the Hanford Environmental Dose Overview Panel.

* Al1 "NO" responses must be explained and use of nonstandard methods justified.

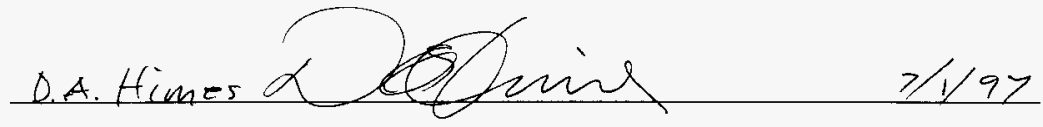

HEDOP-Approved Reviewer (Printed Name and Signature) Date

COMMENTS (add additional signed and dated pages if necessary): 


\section{DISTRIBUTION SHEET}

\begin{tabular}{|c|c|c|c|c|c|}
\hline \multirow{2}{*}{$\begin{array}{l}\text { To } \\
\text { Distribution }\end{array}$} & \multirow{2}{*}{\multicolumn{3}{|c|}{$\begin{array}{l}\text { From } \\
\text { G. W. Ryan }\end{array}$}} & \multicolumn{2}{|l|}{ Page 1 of 1} \\
\hline & & & & \multicolumn{2}{|c|}{ Date $7 / 1 / 97$} \\
\hline \multirow{2}{*}{\multicolumn{4}{|c|}{$\begin{array}{l}\text { Project Title/Work Order } \\
\text { Effects of a Spray Leak Inside the Unloading Area of the } \\
\text { 204-AR Waste Unloading Facility. }\end{array}$}} & \multirow{2}{*}{\multicolumn{2}{|c|}{$\begin{array}{ll}\text { EDT No. } & \text { N/A } \\
\text { ECN No. } & 609902\end{array}$}} \\
\hline & & & & & \\
\hline Name & MSIN & $\begin{array}{l}\text { Text } \\
\text { With All } \\
\text { Attach. }\end{array}$ & Text Only & $\begin{array}{l}\text { Attach./ } \\
\text { Appendix } \\
\text { Only }\end{array}$ & $\begin{array}{c}\text { EDT/ECN } \\
\text { Only }\end{array}$ \\
\hline $\begin{array}{l}\text { D. A. Himes } \\
\text { C. H. Huang } \\
\text { G. W. Ryan (4) } \\
\text { TWRS S \& L Project Files (6) } \\
\text { Central Files (Original + 1) }\end{array}$ & $\begin{array}{l}A 3-34 \\
A 3-34 \\
A 3-37 \\
A 2-26 \\
A 3-88 \\
\end{array}$ & $\begin{array}{l}x \\
x \\
x \\
x \\
x\end{array}$ & & & \\
\hline
\end{tabular}

